\title{
THE INFLUENCE OF AMMONIUM NITRATE AND POTASSIUM HUMATE ON CHEMICAL COMPOSITION OF CALENDULA OFFICINALIS, L. PLANT UNDER TWO TYPES OF SOIL CONDITIONS.
}

Badran, A. Wesam , Selim, S.M., Abdella, M. Ebtsam, Matter, F.M.A

Horticulture Department, Faculty of Agriculture Fayoum University (EGYPT) E-mail: Wa1289@fayoum.edu.eg

\begin{abstract}
An experiment was conducted during 2015/2016 and 2016/2017 growing seasons at the Experimental Farm of Faculty of Agriculture, Fayoum University, Fayoum. The experiment aimed to study the influence of ammonium nitrate and potassium humate on chemical composition of Calendula officinalis, L. plant under two types of soil. The laid-out in a splitsplit plot arranged in randomized complete block design with three replicates. Soil media was considered as main plot in form of two types (clay \& sand loamy soils), while nitrogen fertilizer was in sub-plot in form of ammonium nitrate $(33.5 \% \mathrm{~N})$ at rate of $(0,3$ and $6 \mathrm{~g} / \mathrm{plant})$ and humic acid was in sub-subplot in form of potassium humate $(85 \%)$ at rate of $(0,1$ and $2 \mathrm{~g} / \mathrm{plant})$. The subsub-plot was contained five pots.

The obtained results showed that the interaction between $(6 \mathrm{gm} / \mathrm{plant})$ ammonium nitrate and (2gm/plant) potassium humate increased $\mathrm{N}, \mathrm{P}, \mathrm{K} \%$ compared with the control.

Calendula plants treated with the interaction between ammonium nitrate and potassium humate increased the pigments contents such as (Beta carotene and Xanthophyll ) in dry ray flowers as compared to untreated plants.
\end{abstract}

Key Words: Calendula - Clay and Sand loamy soils -Nitrogen fertilizer Ammonium nitrate -Potassium humate

\section{INTRODUCTION}

Marigold (Calendula officinalis, L.) belongs to Asteraceae family, is a medicinal-ornamental herbaceous annual plant, which is originated from Mediterranean and West Asia. The active substance of this plant is made and stored in its yellow and orange flowers; the most important ones are flavonoids, carotenoids, essential oils, mucilage substances and vitamin "A". This plant is used to treat diseases of the stomach, intestines, and also, the flowers extract is used to dye some types of foods and fats (Mohammadipour et al. 2012).

Referring the effects of growing media, it is well known that soil fertility means the soil capacity to supply the plants with their requirements from nutrients, water and air along the growth season (Askar, 1988).

Fayoum J. Agric. Res. \& Dev., Vol. 33, No.2, July, 2019 
Fertilization with nitrogen, in particular, has been known as a vital step in stepping up the growth and flowering of many ornamental plants (Singh $\boldsymbol{e t}$ al., 1996 and Balak et al., 1999).

Nitrogen, an essential macronutrient in plants is typically present at a concentration of approximately $5 \%$ on a dry mass (DM) basis in floricultural plants, but can reach as high as 7.6\% (Dole and Wilkins, 2005).

Numerous studies have shown beneficial effects of humic substances on soil aggregation, structure, fertility, moisture holding capacity, microbial activity (Chen and Aviad, 1990 and Sharif $\boldsymbol{e t}$ al., 2002), and cation exchange capacity (Marinari et al., 2000). Also, application of humic substances have been shown to increase membrane permeability, oxygen uptake, respiration and photosynthesis, phosphate uptake, nitrogen use efficiency and root elongation (Russo and Berlyn, 1990). Moreover, application of humic substances has stimulatory effects on cytokinin (Zhang and Ervin, 2004) and auxin or gibberellin-like substance along with indirect effect on plant metabolism (Pizzeghello et al., 2001 and Piccolo et al., 1991).

Thus, the present work aimed to study the influence of ammonium nitrate and potassium humate on chemical composition of Calendula officinalis, L. plants under two types of soil conditions.

\section{MATERIALS AND METHODS}

The present work was carried out in the Experimental Farm, Faculty of Agriculture, Fayoum University, during the two successive seasons of $2015 / 2016$ and $2016 / 2017$. The objective of the present study was to investigate the effect of three rates of ammonium nitrate 0,3 and $6 \mathrm{~g} / \mathrm{plant}$ and three soil application rates of potassium humate ( $85 \%$ humic acid) 0,1 and $2 \mathrm{~g} / \mathrm{plant}$ on chemical constituents of marigold (Calendula officinalis, L.) plants under two soil media in a pot experiment.

\section{Plant material}

Uniform of calendula seedlings were obtained from administrative of Ipshaway, Fayoum Governorate, Egypt. The seedlings were (40 day) old were transplanted on $25^{\text {th }}$ of October in the two seasons.

\section{Soil testing}

Some mechanical and chemical analysis of both clay and sand soil used were carried out according to Klute (1986) and Page et al. (1982), respectively. Results of these analyses are shown in Table (1).

Fayoum J. Agric. Res. \& Dev., Vol. 33, No.2, July, 2019 
THE INFLUENCE OF AMMONIUM NITRATE AND POTASSIUM.... 132 Table (1): Some physical and chemical properties of used soils of the experiment during (2015 / 2016) season.

\begin{tabular}{|c|c|c|}
\hline \multicolumn{3}{|c|}{ Physical characters } \\
\hline & \multicolumn{2}{|c|}{$2015 / 2016$} \\
\hline \multirow[t]{2}{*}{ Mechanical analysis } & \multicolumn{2}{|c|}{ Sample number } \\
\hline & 1 & 2 \\
\hline Clay \% & 53.6 & 14.6 \\
\hline Sand $\%$ & 12.1 & 72.5 \\
\hline Silt \% & 34.3 & 12.9 \\
\hline Soil texture & Clay & Sand loamy \\
\hline \multicolumn{3}{|c|}{ Chemical characters } \\
\hline \multicolumn{3}{|c|}{ Chemical analysis } \\
\hline $\mathrm{pH}\left(\right.$ at $\left.25^{\circ} \mathrm{C}\right)$ & 7.38 & 7.86 \\
\hline $\mathrm{ECe}\left(\mathrm{ds} / \mathrm{m} / 25^{\circ} \mathrm{C}\right)$ & 3.30 & 4.70 \\
\hline $\mathrm{CaCO}_{3} \%$ & 4.5 & 7.5 \\
\hline Organic matter \% & 2.2 & 0.90 \\
\hline \multicolumn{3}{|c|}{ Available nutrients $\left(\mathrm{mg} \mathrm{kg}^{-1}\right)$ soil } \\
\hline $\mathrm{N}$ & 30.1 & 14.81 \\
\hline $\mathrm{P}$ & 21.5 & 3.25 \\
\hline $\mathrm{K}$ & 314 & 42.57 \\
\hline $\mathrm{Fe}$ & 18.3 & 4.45 \\
\hline $\mathrm{Mn}$ & 43.6 & 12.5 \\
\hline $\mathrm{Zn}$ & 0.28 & 0.87 \\
\hline
\end{tabular}

Treatments:

Soil media

In both seasons, clay or sand loamy soil was used as a planting medium. Both soils were randomly distributed in the main plots.

Fayoum J. Agric. Res. \& Dev., Vol. 33, No.2, July, 2019 
The plants were received a basic dose from nitrogen fertilizer in the form of ammonium nitrate $(33.5 \% \mathrm{~N})$ at the rate of 0,3 and $6 \mathrm{~g} / \mathrm{pot}$, that divided into two equal portions, which were applied after $4^{\text {th }}$ and $8^{\text {th }}$ weeks from transplanting in both seasons. It was designated as the sub- plots.

Potassium humate

Potassium humate ( $85 \%$ humic acid) was applied to $5 \mathrm{~kg}$ soil/pot during the processing of the ground before planting at the rates of $(0,1$ and $2 \mathrm{~g} / \mathrm{pot})$ and were randomly distributed in the sub- sub- plots.

\section{Experimental design}

The experimental layout used was a split split in randomized complete block design with three replicates. Soil media was considered as main plot, while $\mathrm{N}$ fertilizer was designated as sub-plot and potassium humate was subsub-plot. The sub -sub-plot was contained five pots.

\section{Data recorded:}

- Chemical analysis

- $\quad$ Flower pigments

- $\quad$ Beta carotene and Xanthophyll in dry ray flowers $(\mathrm{mg} / \mathrm{g})$ according to method described in Bacot (1954).

- $\quad$ Percentages of minerals (N, P and K DW) in leaves:

- Nitrogen (N) content was determined according to the method described by Hafez and Mikkelsen (1981).

- Phosphorus (P) content was assessed as described by Jackson (1967).

Page et al. (1982).

Potassium (K) content was assessed as described by

Statistical analysis:

The obtained data were statistically analyzed using the LSD test to compare the means of the different treatments according to Steel and Torrie (1980).

RESULTS AND DISCUSSION

1. Effect of growing media, nitrogen fertilizer and potassium humate and their interactions on chemical composition of Calendula officinalis plants :

1.1. Nitrogen content in leaves (DW):

Growing media:

Growing media indicated a significant effect on nitrogen percentage just in the first season between the clay and sand loamy media, whereas, nitrogen content (\%) was increased as a result of plant growing in the clay medium as compared to plant growing in the sand loamy medium.

Ammonium nitrate:

Fayoum J. Agric. Res. \& Dev., Vol. 33, No.2, July, 2019 
THE INFLUENCE OF AMMONIUM NITRATE AND POTASSIUM.... 134

Data listed in the Table (2) indicate that the gradual increase of ammonium nitrate rate during the two growing seasons, was followed by a gradual increase in nitrogen percentage. The highest $\mathrm{N}$ contents, 3.50 and 3.42 $\mathrm{mg} / \mathrm{g}$ DW were obtained from plant treated with $6 \mathrm{~g}$ ammonium nitrate in the two seasons. The differences between mean values were significant. These results agreed with Matter $\boldsymbol{e t}$ al. (2009) on damsisa, Yassen et al. (2010) on anise and Abd El-Latif (2018) on calotropis plant.

\section{Potassium humate:}

Regarding to $\mathrm{KH}$, data presented in Table (2) show an increase in the two seasons in nitrogen percentage as a result of using $\mathrm{KH}$ compared with control. So, these results refer to the highest values of nitrogen percentage (3.17 and $3.07 \mathrm{mg} / \mathrm{g} \mathrm{DW}$ ) which produced from $2 \mathrm{~g} /$ plant of $\mathrm{KH}$ in the two seasons. There were significant differences between 1 and $2 \mathrm{~g} \mathrm{KH}$ also with control in the first and second seasons. $\mathrm{KH}$ material increased soil organic matter and hence improved the physical, chemical and biological properties. Consequently, the availability of nutrients for plants as well as soil characteristics were improved (El-Ghozoli, 2003).

\section{Effect of growing media and ammonium nitrate interaction:}

Data in the Table (2) represent the comparisons between the growing media and ammonium nitrate which had a significant effect on nitrogen percentage in both seasons. The highest values of nitrogen percentage were 3.52 and $3.46 \mathrm{mg} / \mathrm{g}$ DW which produced from the clay medium with nitrogen fertilizer in form of ammonium nitrate at rate of $(6 \mathrm{~g} / \mathrm{plant})$ in the first and second seasons, respectively. This result agreed with Matter et al. (2009) on damsisa.

\section{Effect of growing media and potassium humate (KH) interaction:}

As shown in the Table (2) it can be concluded that, there was a significant effect on nitrogen percentage resulted due to the interaction between growing media and $\mathrm{KH}$ at different rates in the two seasons of the study. The highest values of nitrogen percentage were ( 3.20 and $3.13 \mathrm{mg} / \mathrm{g} \mathrm{d}$.w.) obtained from the clay medium with humic acid in form of potassium humate at rate of $2 \mathrm{~g}$ in the first and second seasons, respectively.

Effect of ammonium nitrate and potassium humate (KH) interaction:

The interaction effect of ammonium nitrate and potassium humate levels showed a significant difference in plant content of $\mathrm{N}$ in the first and second seasons. The highest values of $\mathrm{N}$ percentage were 3.85 and $3.82 \mathrm{mg} / \mathrm{g}$ DW that obtained from plants treated by the combined treatment of ammonium nitrate (6g/plant) with potassium humate ( $2 \mathrm{~g} / \mathrm{plant})$ compared with control in the first and the second seasons. These results agreed with those obtained by Mazhar $\boldsymbol{e t}$ al. (2012) on chrysanthemum plants, Ali et al. (2014) on Brassica rapa plants and Shahin et al. (2014) on Merremia dissecta plants.

Effect of growing media , ammonium nitrate and Potassium humate (KH) interaction:

Fayoum J. Agric. Res. \& Dev., Vol. 33, No.2, July, 2019 
Badran, A. Wesam, et, al.,

The data presented in Table (2) show a significant effect of growing media, ammonium nitrate and potassium humate and their interactions on nitrogen content in both seasons. The results illustrated a positive relationship between the rates of fertilization with ammonium nitrate on $\mathrm{N}$ content \% in leaves of calendula plant. The rate of $\mathrm{NH}_{4} \mathrm{NO}_{3}(6 \mathrm{~g} /$ plant $)$ with the highest rate of $\mathrm{KH}$ ( $2 \mathrm{~g} / \mathrm{plant})$ under clay and sand loamy media produced the highest mean values of $\mathrm{N}$ content ( 3.89 and $3.81 \mathrm{mg} / \mathrm{g} \mathrm{DW}$ ) in the first season with a significant difference as compared to control. While, in the second season the highest rate of $\mathrm{NH}_{4} \mathrm{NO}_{3} 6 \mathrm{~g} / \mathrm{plant}+$ the rate of potassium humate $2 \mathrm{~g} / \mathrm{plant}$ produced the highest $\mathrm{N}$ content $(3.88$ and $3.76 \mathrm{mg} / \mathrm{g} \mathrm{DW})$ with a significant difference as compared to the control.

Table (2): Effect of growing media, nitrogen fertilizer and potassium humate on nitrogen content \% of plant of calendula during 2015/2016 and 2016/2017 seasons.

\begin{tabular}{|c|c|c|c|c|c|c|c|c|c|}
\hline \multirow{3}{*}{ Soil type } & \multirow{3}{*}{$\underset{\text { nitrate }(g / \text { plant })}{\text { Ammonium }}$} & \multirow{2}{*}{\multicolumn{4}{|c|}{$\begin{array}{c}\text { Frist season (2015/2016) } \\
\text { Potassium humate (g/plant) } \\
\end{array}$}} & \multirow{2}{*}{\multicolumn{4}{|c|}{$\begin{array}{l}\text { Second season }(2016 / 2017) \\
\text { Potassium humate (g/plant) } \\
\end{array}$}} \\
\hline & & & & & & & & & \\
\hline & & $\mathbf{0}$ & 1 & 2 & $\begin{array}{l}\text { Mean } \\
(\mathbf{S} * \mathbf{N}) \\
\end{array}$ & $\mathbf{0}$ & 1 & 2 & $\operatorname{Mean}\left(\mathbf{S}^{*} \mathbf{N}\right)$ \\
\hline \multirow{3}{*}{ Clay } & 0 & 2.05 & 2.27 & 2.44 & 2.25 & 2.06 & 2.27 & 2.44 & 2.26 \\
\hline & 3 & 2.45 & 3.05 & 3.27 & 2.92 & 2.45 & 2.85 & 3.07 & 2.79 \\
\hline & 6 & 3.30 & 3.38 & 3.89 & 3.52 & 3.21 & 3.29 & 3.88 & 3.46 \\
\hline \multirow{3}{*}{ Sand loamy } & 0 & 2.02 & 2.16 & 2.38 & 2.19 & 2.00 & 2.14 & 2.34 & 2.16 \\
\hline & 3 & 2.41 & 3.03 & 3.25 & 2.90 & 2.39 & 2.74 & 2.92 & 2.68 \\
\hline & 6 & 3.27 & 3.35 & 3.81 & 3.48 & 3.15 & 3.22 & 3.76 & 3.38 \\
\hline \multicolumn{2}{|c|}{ Mean $(\mathrm{KH})$} & 2.58 & 2.87 & 3.17 & \multirow{4}{*}{$\begin{array}{l}\text { Mean } \\
\text { (S) }\end{array}$} & 2.54 & 2.75 & 3.07 & \multirow{4}{*}{ Mean (S) } \\
\hline \multirow{3}{*}{ L.S.D 0.05} & KH & \multicolumn{3}{|c|}{0.03} & & \multicolumn{3}{|c|}{0.10} & \\
\hline & $\mathbf{S} * \mathbf{N}$ & \multicolumn{3}{|c|}{0.05} & & \multicolumn{3}{|c|}{0.15} & \\
\hline & $S * N * K H$ & \multicolumn{3}{|c|}{0.08} & & \multicolumn{3}{|c|}{0.25} & \\
\hline \multirow{2}{*}{$\begin{array}{c}\text { Mean } \\
(\mathbf{S} * \mathbf{K H})\end{array}$} & Clay & 2.60 & 2.90 & 3.20 & 2.90 & 2.57 & 2.80 & 3.13 & 2.84 \\
\hline & Sand loamy & 2.57 & 2.85 & 3.15 & 2.85 & 2.51 & 2.70 & 3.01 & 2.74 \\
\hline \multirow[t]{2}{*}{ L.S.D 0.05} & $\mathbf{S}$ & \multicolumn{3}{|c|}{0.03} & Mean & \multicolumn{3}{|c|}{0.18} & $\operatorname{Mean}(\mathbf{N})$ \\
\hline & $\mathbf{S * K H}$ & \multicolumn{3}{|c|}{0.14} & & \multicolumn{3}{|c|}{0.05} & \\
\hline \multirow{3}{*}{$\begin{array}{l}\text { Mean } \\
(\mathbf{N} * \mathbf{K H})\end{array}$} & $\mathbf{0}$ & 2.04 & 2.22 & 2.41 & 2.22 & 2.03 & 2.21 & 2.39 & 2.21 \\
\hline & 3 & 2.43 & 3.04 & 3.26 & 2.91 & 2.42 & 2.80 & 3.00 & 2.74 \\
\hline & 6 & 3.29 & 3.37 & 3.85 & 3.50 & 3.18 & 3.26 & 3.82 & 3.42 \\
\hline \multirow{2}{*}{$\begin{array}{l}\text { L.S.D } \\
0.05\end{array}$} & $\mathbf{N}$ & \multicolumn{4}{|c|}{0.03} & \multicolumn{4}{|c|}{0.11} \\
\hline & $\mathbf{N}^{*} \mathbf{K H}$ & \multicolumn{4}{|c|}{0.06} & \multicolumn{4}{|c|}{0.17} \\
\hline
\end{tabular}

Fayoum J. Agric. Res. \& Dev., Vol. 33, No.2, July, 2019 


\section{Growing media:}

Growing media gave a significant effect on $\mathrm{P}$ percentage in the both seasons, whereas, $\mathrm{P}$ percentage increased as a result of growing in clay medium as compared of growing in sand loamy medium.

\section{Ammonium nitrate:}

Data listed in the Table (3) indicate that gradual increase of ammonium nitrate rate during the two growing seasons, was followed by a gradual increase in phosphorus percentage. The highest $P$ contents were $(0.38$ and $0.36 \mathrm{mg} / \mathrm{g}$ d.w.) obtained from plants treated with $6 \mathrm{~g}$ ammonium nitrate in the two seasons. The differences between mean values were significant. These results agreed with Matter et al. (2009) on damsisa, Yassen et al. (2010) on anise, Abbasi et al. (2012) on amaranth and Abd El-Latif (2018) on calotropis plant.

\section{Potassium humate:}

As for humic acid, data presented in Table (3) show an increase in the two seasons in $\mathrm{P}$ percentage as a result of using potassium humate as compared with control. The highest values of phosphorus percentage were $(0.35$ and $0.33 \mathrm{mg} / \mathrm{g}$ d.w.) given by the highest rate of potassium humate $(2 \mathrm{~g} /$ plant $)$ in the first and second seasons, there were significant differences between the treatments (1 and $2 \mathrm{~g}$ ). Humic acid materials increase soil organic matter, particularly for the sandy soils in Egypt, and hence improve the physical, chemical and biological properties. Consequently, the availability of nutrients for plants as well as soil characteristics should be improved, El-Ghozoli (2003) on faba bean plants. These results agreed with Cimrin and Yilmaz (2005) on lettuce and Matter (2015) on marigold plant.

\section{Effect of growing media and ammonium nitrate interaction:}

Data in the Table (3) represent the comparisons among the means of the various treatments combinations of growing media and ammonium nitrate which had a significant effect on phosphorus percentage in the both seasons and from the Table (3) the highest values of phosphorus percentage were $(0.39$ and $0.38 \mathrm{mg} / \mathrm{g}$ d.w.) obtained from the clay medium with nitrogen fertilizer in form of ammonium nitrate at rate of $6 \mathrm{~g} /$ plant in the first and second seasons. While, the lowest values were $(0.24$ and $0.25 \mathrm{mg} / \mathrm{g} \mathrm{d.w.})$ produced from untreated plant (control).

\section{Effect of growing media and potassium humate (KH) interaction:}

As shown in the Table (3) it can be concluded that, there was significant effect on phosphorus percentage due to the interaction between growing media and $\mathrm{KH}$ at different rates in the two seasons of study. The highest values of phosphorus percentage were $(0.36$ and $0.34 \mathrm{mg} / \mathrm{g} \mathrm{d}$.w. $)$ obtained from the clay medium with humic acid in form of $\mathrm{KH}$ at rate of $2 \mathrm{~g}$ through the two seasons of the study.

Fayoum J. Agric. Res. \& Dev., Vol. 33, No.2, July, 2019 
Badran, A. Wesam, et, al.,

Effect of ammonium nitrate and potassium humate $(\mathrm{KH})$ interaction:

The interaction effect of ammonium nitrate rate and $\mathrm{KH}$ levels show significantly differences in plant content of phosphorus percentage in the two seasons. The highest values of $P$ percentage were $(0.41$ and $0.39 \mathrm{mg} / \mathrm{g} \mathrm{d.w}$.) in the two seasons obtained from plants treated by the combined treatment $6 \mathrm{~g}$ of ammonium nitrate $+2 \mathrm{~g}$ of $\mathrm{KH}$ /plant compared with control. These results agreed with those obtained by Mazhar et al. (2012) on chrysanthemum plants, Ali et al. (2014) on Brassica rapa plants and Shahin et al. (2014) on Merremia dissecta plants.

Effect of growing media, ammonium nitrate and Potassium humate (KH) interaction:

The data presented in Table (3) show the effect of growing media, ammonium nitrate and $\mathrm{KH}$ and their interactions on phosphorus percentage in both seasons. The results indicated a positive relationship between the rates of fertilization with growing media on phosphorus percentage in leaves of calendula plants. The highest rate of $\mathrm{NH}_{4} \mathrm{NO}_{3}(6 \mathrm{~g} /$ plant $)$ with the highest rate of $\mathrm{KH}(2 \mathrm{~g} / \mathrm{plant})$ under clay medium produced the highest phosphorus percentage in the two seasons with a significant difference as compared to the control.

Table (3): Effect of growing media, nitrogen fertilizer and potassium humate on phosphorus content $\%$ in leaves of calendula during 2015/2016 and 2016/2017 seasons.

\begin{tabular}{|c|c|c|c|c|c|c|c|c|c|}
\hline \multirow{3}{*}{ Soil type } & \multirow{3}{*}{$\begin{array}{c}\text { Ammonium } \\
\text { nitrate } \\
\text { (g/plant) }\end{array}$} & \multirow{2}{*}{\multicolumn{4}{|c|}{$\begin{array}{c}\text { Frist season (2015/2016) } \\
\text { Potassium humate (g/plant) }\end{array}$}} & \multicolumn{4}{|c|}{ Second season $(2016 / 2017)$} \\
\hline & & & & & & \multicolumn{4}{|c|}{ Potassium humate (g/plant) } \\
\hline & & $\mathbf{0}$ & 1 & 2 & $\begin{array}{l}\text { Mean } \\
(\mathbf{S} * \mathbf{N}) \\
\end{array}$ & $\mathbf{0}$ & 1 & 2 & $\begin{array}{l}\text { Mean } \\
\left(S^{*} \mathbf{N}\right) \\
\end{array}$ \\
\hline \multirow{3}{*}{ Clay } & $\mathbf{0}$ & 0.23 & 0.27 & 0.30 & 0.27 & 0.22 & 0.25 & 0.29 & 0.25 \\
\hline & 3 & 0.31 & 0.34 & 0.36 & 0.34 & 0.29 & 0.31 & 0.34 & 0.31 \\
\hline & 6 & 0.37 & 0.39 & 0.42 & 0.39 & 0.36 & 0.37 & 0.40 & 0.38 \\
\hline \multirow{3}{*}{ Sand loamy } & $\mathbf{0}$ & 0.21 & 0.23 & 0.27 & 0.24 & 0.19 & 0.21 & 0.25 & 0.22 \\
\hline & 3 & 0.28 & 0.31 & 0.33 & 0.31 & 0.26 & 0.29 & 0.31 & 0.29 \\
\hline & 6 & 0.35 & 0.36 & 0.39 & 0.37 & 0.31 & 0.34 & 0.37 & 0.34 \\
\hline \multicolumn{2}{|c|}{ Mean $($ KH) } & 0.29 & $\mathbf{0 . 3 2}$ & $\mathbf{0 . 3 5}$ & \multirow{4}{*}{$\begin{array}{c}\text { Mean } \\
\text { (S) }\end{array}$} & 0.27 & $\mathbf{0 . 3 0}$ & $\mathbf{0 . 3 3}$ & \multirow{4}{*}{ Mean (S) } \\
\hline \multirow{3}{*}{ L.S.D 0.05} & KH & \multicolumn{3}{|c|}{0.002} & & \multicolumn{3}{|c|}{0.005} & \\
\hline & $\mathbf{S * N}$ & \multirow{2}{*}{\multicolumn{3}{|c|}{\begin{tabular}{|l|}
0.003 \\
0.005
\end{tabular}}} & & \multicolumn{3}{|c|}{0.007} & \\
\hline & $\mathbf{S} * \mathbf{N} * \mathbf{K H}$ & & & & & \multicolumn{3}{|c|}{0.012} & \\
\hline \multirow{2}{*}{$\begin{array}{c}\text { Mean } \\
\left(\mathbf{S}^{*} \mathbf{K H}\right)\end{array}$} & Clay & 0.30 & 0.33 & 0.36 & $\mathbf{0 . 3 3}$ & 0.29 & 0.31 & 0.34 & 0.31 \\
\hline & Sand loamy & 0.28 & 0.30 & 0.33 & $\mathbf{0 . 3 0}$ & 0.25 & 0.28 & 0.31 & 0.28 \\
\hline \multirow{2}{*}{ L.S.D 0.05} & $\mathbf{S}$ & \multirow{2}{*}{\multicolumn{3}{|c|}{0.002}} & Mean & \multirow{2}{*}{\multicolumn{3}{|c|}{0.004}} & $\operatorname{Mean}(\mathbf{N})$ \\
\hline & $\mathbf{S}^{*} \mathbf{K H}$ & & & & $(\mathbf{N})$ & & & & Mean (N) \\
\hline \multirow{3}{*}{$\begin{array}{c}\text { Mean } \\
\left(\mathbf{N}^{*} \mathbf{K H}\right)\end{array}$} & $\mathbf{0}$ & 0.22 & 0.25 & 0.29 & 0.25 & 0.21 & 0.23 & 0.27 & 0.24 \\
\hline & 3 & 0.30 & 0.33 & 0.35 & 0.32 & 0.28 & 0.30 & 0.33 & $\mathbf{0 . 3 0}$ \\
\hline & 6 & 0.36 & 0.38 & 0.41 & $\mathbf{0 . 3 8}$ & 0.34 & 0.36 & 0.39 & 0.36 \\
\hline \multirow{2}{*}{ L.S.D o.o5 } & $\mathbf{N}$ & \multicolumn{4}{|c|}{0.002} & \multicolumn{4}{|c|}{0.005} \\
\hline & $\mathbf{N * K H}$ & \multicolumn{4}{|c|}{0.004} & \multicolumn{4}{|c|}{0.008} \\
\hline
\end{tabular}

Fayoum J. Agric. Res. \& Dev., Vol. 33, No.2, July, 2019 
THE INFLUENCE OF AMMONIUM NITRATE AND POTASSIUM.... 138 1.3. Potassium content:

Growing media:

Growing media gave a significant effect on potassium percentage only in the first season, whereas, potassium percentage increased as a result of growing in clay medium as compared to growing in sand loamy medium.

Ammonium nitrate:

Data listed in the Table (4) indicate that the gradual increase of ammonium nitrate rate during the two growing seasons, was followed by a gradual increase in potassium percentage. The highest $\mathrm{K}$ percentage contents were $(1.88$ and $1.86 \mathrm{mg} / \mathrm{g}$ d.w.) obtained from plants treated with $6 \mathrm{~g}$ ammonium nitrate in the two seasons. The differences between mean values were significant. These results agreed with Matter $\boldsymbol{e t}$ al. (2009) on damsisa, Yassen et al. (2010) on anise and Abd El-Latif (2018) on calotropis plant.

Potassium humate:

Concerning KH, data presented in Table (4) show an increase in the two seasons in potassium content as a result of using $\mathrm{KH}$ compared with control, the highest values of $\mathrm{K}$ content were $(1.83$ and $1.76 \mathrm{mg} / \mathrm{g}$ d.w.) obtained from $(2 \mathrm{~g} / \mathrm{plant}) \mathrm{KH}$ in the first and second seasons, respectively. There were significant differences between $(1$ and $2 \mathrm{~g})$ in the first and second seasons. Humic acid materials increase soil organic matter, particularly for the sandy soils in Egypt, and hence improve the physical, chemical and biological properties. Consequently, the availability of nutrients for plants as well as soil characteristics should be improved, El-Ghozoli (2003) on faba bean. These results agreed with Nikbakhl et al. (2008) on gerbera and Shafeek et al. (2015) on Allium sativum plants. Effect of growing media and ammonium nitrate interaction:

Data in the Table (4) explain the comparisons among the means of the various treatments combinations of growing media and ammonium nitrate which had a significant effect on potassium percentage in the first and second seasons. The highest values in Table (18) were (1.89 and $1.87 \mathrm{mg} / \mathrm{g}$ d.w.) obtained from (6g/plant ammonium nitrate) under clay soil in the two seasons.

Effect of growing media and potassium humate $(\mathrm{KH})$ interaction:

As shown in the Table (4) it can be concluded that, there was significant effect on potassium content due to the interaction between growing media and $\mathrm{KH}$ at different rates in both seasons of the study. The highest values of $\mathrm{K}$ content were $(1.84$ and $1.77 \mathrm{mg} / \mathrm{g}$ d.w.) obtained from the clay medium with humic acid in form of $\mathrm{KH}$ at rate of $(2 \mathrm{~g} / \mathrm{plant})$ in the first season and in the second season, respectively.

Effect of ammonium nitrate and potassium humate (KH) interaction:

The interaction effect of ammonium nitrate rates and $\mathrm{KH}$ levels showed a significant difference in plant content of $\mathrm{K}$ in the both seasons. The highest values of $\mathrm{K}$ content in the two seasons were obtained from plants treated by the combined treatment $(6 \mathrm{~g}$ of ammonium nitrate with $2 \mathrm{~g}$ of $\mathrm{KH} / \mathrm{plant}$ ) compared with control. These results agreed with those obtained by Mazhar et al. (2012) on chrysanthemum, Ali et al. (2014) on Brassica rapa and Shahin et al. (2014) on Merremia dissecta plants.

Effect of growing media, ammonium nitrate and Potassium humate (KH) interaction:

The data presented in Table (4) show that there was a positive relationship between the rates of fertilization with ammonium nitrate and $\mathrm{KH}$ under clay and sand loamy media on potassium content in leaves of calendula plants and the interaction between growing, ammonium nitrate and $\mathrm{KH}$ had not significant effect on potassium content in the two

Fayoum J. Agric. Res. \& Dev., Vol. 33, No.2, July, 2019 
Badran, A. Wesam, et, al.,

seasons . The highest rate of $\mathrm{NH}_{4} \mathrm{NO}_{3}(6 \mathrm{~g} / \mathrm{plant})$ with the rate of $\mathrm{KH}(2 \mathrm{~g} / \mathrm{plant})$ produced the highest potassium content in the both seasons under clay medium with a significant difference as compared to the control.

Table (4): Effect of growing media, nitrogen fertilizer and potassium humate on potassium content $\%$ in leaves of calendula during

\begin{tabular}{|c|c|c|c|c|c|c|c|c|c|}
\hline \multirow{3}{*}{ Soil type } & \multirow{3}{*}{$\begin{array}{c}\text { Ammonium } \\
\text { nitrate } \\
\text { (g/plant) }\end{array}$} & \multicolumn{4}{|c|}{ Frist season $(2015 / 2016)$} & \multicolumn{4}{|c|}{ Second season $(2016 / 2017)$} \\
\hline & & \multicolumn{4}{|c|}{ Potassium humate (g/plant) } & \multicolumn{4}{|c|}{ Potassium humate (g/plant) } \\
\hline & & $\mathbf{0}$ & 1 & 2 & $\begin{array}{l}\text { Mean } \\
\left(\mathbf{S}^{*} \mathbf{N}\right)\end{array}$ & $\mathbf{0}$ & 1 & 2 & $\operatorname{Mean}\left(\mathbf{S}^{*} \mathbf{N}\right)$ \\
\hline \multirow{3}{*}{ Clay } & $\mathbf{0}$ & 1.51 & 1.52 & 1.74 & 1.59 & 1.47 & 1.49 & 1.61 & 1.52 \\
\hline & 3 & 1.75 & 1.83 & 1.85 & 1.81 & 1.65 & 1.77 & 1.81 & 1.74 \\
\hline & 6 & 1.87 & 1.89 & 1.92 & 1.89 & 1.83 & 1.87 & 1.90 & 1.87 \\
\hline \multirow{3}{*}{ Sand loamy } & $\mathbf{0}$ & 1.41 & 1.45 & 1.73 & 1.53 & 1.39 & 1.42 & 1.59 & 1.47 \\
\hline & 3 & 1.74 & 1.81 & 1.83 & 1.79 & 1.62 & 1.75 & 1.79 & 1.72 \\
\hline & 6 & 1.85 & 1.87 & 1.90 & 1.87 & 1.82 & 1.84 & 1.87 & 1.84 \\
\hline \multicolumn{2}{|c|}{ Mean $(\mathrm{KH})$} & 1.69 & 1.73 & 1.83 & \multirow{4}{*}{$\begin{array}{c}\text { Mean } \\
\text { (S) }\end{array}$} & 1.63 & 1.69 & 1.76 & \multirow{4}{*}{ Mean (S) } \\
\hline \multirow{3}{*}{ L.S.D o.05 } & KH & \multicolumn{3}{|c|}{0.026} & & \multicolumn{3}{|c|}{0.023} & \\
\hline & $\mathbf{S}^{*} \mathbf{N}$ & \multicolumn{3}{|c|}{0.030} & & \multicolumn{3}{|c|}{0.019} & \\
\hline & $\mathbf{S} * \mathbf{N} * \mathbf{K H}$ & \multicolumn{3}{|c|}{0.065} & & \multicolumn{3}{|c|}{0.056} & \\
\hline \multirow{2}{*}{$\begin{array}{c}\text { Mean } \\
(\mathbf{S} * \mathbf{K H})\end{array}$} & Clay & 1.71 & 1.75 & 1.84 & 1.76 & 1.65 & 1.71 & 1.77 & 1.71 \\
\hline & Sand loamy & 1.67 & 1.71 & 1.82 & 1.73 & 1.61 & 1.67 & 1.75 & 1.68 \\
\hline \multirow{2}{*}{ L.S.D o.o5 } & $\mathbf{S}$ & \multicolumn{3}{|c|}{0.023} & Mean & \multicolumn{3}{|c|}{0.041} & \multirow{2}{*}{$\operatorname{Mean}(\mathbf{N})$} \\
\hline & S*KH & \multicolumn{3}{|c|}{0.037} & & \multicolumn{3}{|c|}{0.032} & \\
\hline \multirow{3}{*}{$\begin{array}{c}\text { Mean } \\
\left(\mathbf{N}^{*} \mathbf{K H}\right)\end{array}$} & 0 & 1.46 & 1.49 & 1.74 & 1.56 & 1.43 & 1.46 & 1.60 & 1.50 \\
\hline & 3 & 1.75 & 1.82 & 1.84 & 1.80 & 1.64 & 1.76 & 1.80 & 1.73 \\
\hline & 6 & 1.86 & 1.88 & 1.91 & 1.88 & 1.83 & 1.86 & 1.89 & 1.86 \\
\hline \multirow{2}{*}{ L.S.D 0.05} & $\mathbf{N}$ & \multicolumn{4}{|c|}{0.021} & \multicolumn{4}{|c|}{0.014} \\
\hline & $\mathbf{N} * \mathbf{K H}$ & \multicolumn{4}{|c|}{0.046} & \multicolumn{4}{|c|}{0.039} \\
\hline
\end{tabular}

Fayoum J. Agric. Res. \& Dev., Vol. 33, No.2, July, 2019 
THE INFLUENCE OF AMMONIUM NITRATE AND POTASSIUM.... 140

2. Effect of growing media, nitrogen fertilizer, potassium humate (KH) and their interactions on flower's pigments contents:

\subsection{Beta carotene :}

\section{Growing media:}

From the Table (4) growing media gave a significant effect on beta carotene contents of inflorescences in the first and second seasons, whereas, the highest beta carotene contents were obtained under clay soil as compared to sand loamy soil condition.

\section{Ammonium nitrate:}

Data listed in the Table (4) indicate that the gradual increase of ammonium nitrate rate during the two growing seasons, was followed by a gradual increase in beta carotene contents. The highest beta carotene contents were $(0.72$ and $0.76 \mathrm{mg} / \mathrm{g}$ d.w.) obtained from nitrogen fertilizer in form of ammonium nitrate at rate of (6 g/plant) in the two and differences between mean values were significant as compared to control.

Potassium humate (KH):

Data presented in Table (4) show a significant increase between the two seasons in beta carotene contents as a result of using $\mathrm{KH}$ as compared with control. There were significant differences between ( 1 and $2 \mathrm{~g}$ ) in the first and second seasons. This result agreed with Matter (2015) on Calendula officinalis plant.

Effect of growing media and ammonium nitrate interaction:

Data in the Table (4) refer to the comparisons among the means of the various treatments combinations of sowing media and ammonium nitrate which had a significant effect on beta carotene contents of inflorescences in the first and second seasons and from the Table (4) the highest values of beta carotene content were $(0.73$ and $0.77 \mathrm{mg} / \mathrm{g} \mathrm{d}$.w. ) from $6 \mathrm{~g}$ ammonium nitrate under clay soil in the two seasons.

Effect of growing media and potassium humate (KH) interaction:

As shown in the Table (4) there was a significant effect on beta carotene contents due to the interaction between growing media and $\mathrm{KH}$ at different rates in both seasons of the study. The highest values were $(0.69$ and $0.68 \mathrm{mg} / \mathrm{g} \mathrm{d} . \mathrm{w}$.) obtained from humic acid in form of $\mathrm{KH}$ at the rate of $(2 \mathrm{~g} / \mathrm{plant})$ in the two seasons and there were significant differences between two growing media.

\section{Effect of ammonium nitrate and potassium humate (KH) interaction:}

Regarding to the interactive effect of ammonium nitrate and $\mathrm{KH}$ the obtained results indicated that beta carotene contents were significantly affected by this interaction and the highest contents of beta carotene were $(0.77$ and 0.78 $\mathrm{mg} / \mathrm{g}$ d.w) obtained from plants treated with the rate of ammonium nitrate $6 \mathrm{~g} / \mathrm{plant}+$ the level of $\mathrm{KH} 2 \mathrm{~g} /$ plant in the first and second seasons. Similar results were reported by Sifola, Maria and Barbieri (2006) on Ocimum basilicum L. , Gomaa and Youssef (2008) on caraway, Prakash et al. (2012)

Fayoum J. Agric. Res. \& Dev., Vol. 33, No.2, July, 2019 
Badran, A. Wesam, et, al.,

on Stevia rebaudiana, Ibrahim (2013) on datura and Shafeek et al. (2016) on Cucurbita pepo plants.

Effect of growing media, ammonium nitrate and Potassium humate (KH) interaction:

The data presented in Table (4) show the effect of the interactions on beta carotene in both seasons. The rates of $\mathrm{NH}_{4} \mathrm{NO}_{3} 6 \mathrm{~g} / \mathrm{plant}+$ the rate of $\mathrm{KH}$ $2 \mathrm{~g} /$ plant produced the highest beta carotene content $(0.78 \mathrm{mg} / \mathrm{g} \mathrm{d} . \mathrm{w}$. $)$ under clay soil condition and $(0.75 \mathrm{mg} / \mathrm{g}$ d.w. $)$ under sand loamy soil in the first season with a significant difference as compared to the control. While, in the second season the highest beta carotene content was $(0.79 \mathrm{mg} / \mathrm{g} \mathrm{d.w.})$ obtained from the rates of $\mathrm{NH}_{4} \mathrm{NO}_{3} 6 \mathrm{~g} /$ plant + the rate of $\mathrm{KH} 2 \mathrm{~g} /$ plant under clay and produced $(0.77 \mathrm{mg} / \mathrm{g}$ d.w. $)$ under sand loamy medium with a significant difference as compared to the control.

Table (4): Effect of growing media, nitrogen fertilizer and potassium humate on beta Carotene content (mg/g DW) of inflorescence of calendula during 2015/2016 and 2016/2017 seasons.

\begin{tabular}{|c|c|c|c|c|c|c|c|c|c|}
\hline \multirow{3}{*}{ Soil type } & \multirow{3}{*}{$\begin{array}{l}\text { Ammonium } \\
\text { nitrate (g/plant) }\end{array}$} & \multirow{2}{*}{\multicolumn{4}{|c|}{$\frac{\text { Frist season }(2015 / 2016)}{\text { Potassium humate (g/plant) }}$}} & \multirow{2}{*}{\multicolumn{4}{|c|}{$\begin{array}{l}\text { Second season }(2016 / 2017) \\
\text { Potassium humate (g/plant) }\end{array}$}} \\
\hline & & & & & & & & & \\
\hline & & 0 & 1 & 2 & $\begin{array}{l}\text { Mean } \\
(\mathbf{S} * \mathbf{N})\end{array}$ & $\mathbf{0}$ & 1 & 2 & $\begin{array}{l}\text { Mean } \\
\left(\mathbf{S}^{*} \mathbf{N}\right)\end{array}$ \\
\hline \multirow{3}{*}{ Clay } & 0 & 0.38 & 0.54 & 0.62 & 0.51 & 0.39 & 0.56 & 0.69 & 0.55 \\
\hline & 3 & 0.64 & 0.66 & 0.67 & 0.66 & 0.69 & 0.72 & 0.73 & 0.71 \\
\hline & 6 & 0.69 & 0.72 & 0.78 & 0.73 & 0.75 & 0.77 & 0.79 & 0.77 \\
\hline \multirow{3}{*}{ Sand loamy } & 0 & 0.35 & 0.46 & 0.52 & 0.44 & 0.36 & 0.52 & 0.57 & 0.48 \\
\hline & 3 & 0.59 & 0.62 & 0.66 & 0.62 & 0.61 & 0.64 & 0.70 & 0.65 \\
\hline & 6 & 0.68 & 0.70 & 0.75 & 0.71 & 0.72 & 0.73 & 0.77 & 0.74 \\
\hline \multicolumn{2}{|c|}{ Mean $(\mathrm{KH})$} & 0.56 & 0.62 & 0.67 & \multirow{4}{*}{ Mean (S) } & 0.59 & 0.66 & 0.71 & \multirow{4}{*}{ Mean $(S)$} \\
\hline \multirow{3}{*}{ L.S.D 0.05} & KH & \multicolumn{3}{|c|}{0.01} & & & 0.02 & & \\
\hline & $\mathbf{S * N}$ & \multicolumn{3}{|c|}{0.03} & & \multicolumn{3}{|c|}{0.03} & \\
\hline & S*N*KH & \multicolumn{3}{|c|}{0.03} & & \multicolumn{3}{|c|}{0.03} & \\
\hline \multirow{2}{*}{$\begin{array}{l}\text { Mean } \\
(\mathbf{S} * \mathbf{K H})\end{array}$} & Clay & 0.57 & 0.64 & 0.69 & 0.63 & 0.61 & 0.68 & 0.74 & 0.68 \\
\hline & Sand loamy & 0.54 & 0.59 & 0.64 & 0.59 & 0.56 & 0.63 & 0.68 & 0.62 \\
\hline \multirow[t]{2}{*}{ L.S.D 0.05} & $\mathbf{S}$ & \multicolumn{3}{|c|}{0.02} & $\operatorname{Mean}(\mathbf{N})$ & \multicolumn{3}{|c|}{0.04} & \multirow[t]{2}{*}{$\operatorname{Mean}(\mathbf{N})$} \\
\hline & $\mathbf{S * K H}$ & \multicolumn{3}{|c|}{0.02} & & \multicolumn{3}{|c|}{0.03} & \\
\hline \multirow{3}{*}{$\begin{array}{c}\text { Mean } \\
\left(\mathbf{N}^{*} \mathbf{K H}\right)\end{array}$} & $\mathbf{0}$ & 0.37 & 0.50 & 0.57 & 0.48 & 0.38 & 0.54 & 0.63 & 0.52 \\
\hline & 3 & 0.62 & 0.64 & 0.67 & 0.64 & 0.65 & 0.68 & 0.72 & 0.68 \\
\hline & 6 & 0.69 & 0.71 & 0.77 & 0.72 & 0.74 & 0.75 & 0.78 & 0.76 \\
\hline \multirow{2}{*}{ L.S.D 0.05} & $\mathbf{N}$ & \multicolumn{4}{|c|}{0.02} & \multicolumn{4}{|c|}{0.01} \\
\hline & $\mathbf{N}$ KH & \multicolumn{4}{|c|}{0.02} & \multicolumn{4}{|c|}{0.03} \\
\hline
\end{tabular}

Fayoum J. Agric. Res. \& Dev., Vol. 33, No.2, July, 2019 


\section{2. Xanthophyll:}

\section{Growing media:}

Growing media gave a significant effect on xanthophyll contents of inflorescences in the first and second seasons between the two growing media.

\section{Ammonium nitrate:}

Data listed in the Table (5) indicate that the gradual increase of ammonium nitrate rate during the two growing seasons, was followed by a gradual increase in xanthophyll contents. The highest xanthophyll contents were $(0.35$ and $0.38 \mathrm{mg} / \mathrm{g}$ d.w. $)$ obtained from plants treated with $6 \mathrm{~g} / \mathrm{plant}$ ammonium nitrate in the two seasons. The differences between mean values were significant as compared to control.

\section{potassium humate $(\mathrm{KH})$ :}

Data presented in Table (5) illustrate a significant increase between the two seasons in xanthophyll contents as a result of using $\mathrm{KH}$ as compared to control. There were significant differences between (1 and $2 \mathrm{~g})$ in the first and second seasons. This result agreed with Matter (2015) on Calendula officinalis plant.

\section{Effect of growing media and ammonium nitrate interaction:}

Data in the Table (5) expose the comparisons among the means of the various treatment's combinations of growing media and ammonium nitrate which had a significant effect on xanthophyll contents of inflorescences in the first and second seasons and from the Table (5) the highest values of xanthophyll contents were $(0.36$ and $0.39 \mathrm{mg} / \mathrm{g} \mathrm{d.w.}$ ) obtained from nitrogen fertilizer in form of ammonium nitrate at rate of $6 \mathrm{~g}$ under clay soil in the two seasons.

\section{Effect of growing media and potassium humate (KH) interaction:}

As shown in the Table (5) there was a significant effect on xanthophyll contents due to the interaction between growing media and $\mathrm{KH}$ at different rates in both seasons of the study. The highest values were $(0.33$ and $0.35 \mathrm{mg} / \mathrm{g} \mathrm{d} . \mathrm{w}$.) obtained from the clay medium with humic acid in form of $\mathrm{KH}$ at rate of $(2 \mathrm{~g} /$ plant $)$ in the first and second seasons, respectively.

\section{Effect of ammonium nitrate and potassium humate (KH) interaction:}

As for the interactive effect of ammonium nitrate and $\mathrm{KH}$ the obtained results indicate that xanthophyll contents were significantly affected by this interaction and the highest values of xanthophyll content $(0.38$ and $0.40 \mathrm{mg} / \mathrm{g}$ d.w) in the first and second seasons obtained from plants treated with the rate of ammonium nitrate $6 \mathrm{~g} / \mathrm{plant}+$ the highest level of potassium humate $2 \mathrm{~g} / \mathrm{plant}$. Similar results were reported by Sifola, Maria and Barbieri (2006) on Ocimum basilicum L. , Gomaa and Youssef (2008) on caraway, Prakash et al. (2012) on Stevia Rebaudiana, Ibrahim (2013) on datura and Shafeek et al. (2016) on Cucurbita pepo plants.

Fayoum J. Agric. Res. \& Dev., Vol. 33, No.2, July, 2019 
Badran, A. Wesam, et, al.,

Effect of growing media , ammonium nitrate and Potassium humate (KH) interaction:

The data presented in Table (5) show a significant effect of interactions between growing media, ammonium nitrate and $\mathrm{KH}$ on xanthophyll contents in both seasons. The highest rate of $\mathrm{NH}_{4} \mathrm{NO}_{3} 6 \mathrm{~g} /$ plant + the highest rate of $\mathrm{KH} 2$ $\mathrm{g} /$ plant produced the highest xanthophyll contents under clay medium in the two seasons with a significant difference as compared to the control.

Table (5): Effect of growing media, nitrogen fertilizer and potassium humate on xanthophyll contents (mg/g DW) of inflorescences of calendula during 2015/2016 and 2016/2017 seasons.

\begin{tabular}{|c|c|c|c|c|c|c|c|c|c|}
\hline \multirow{3}{*}{ Soil type } & \multirow{3}{*}{$\begin{array}{c}\text { Ammonium } \\
\text { nitrate } \\
\text { (g/plant) }\end{array}$} & \multirow{2}{*}{\multicolumn{4}{|c|}{$\frac{\text { Frist season }(2015 / 2016)}{\text { Potassium humate (g/plant) }}$}} & \multirow{2}{*}{\multicolumn{4}{|c|}{$\frac{\text { Second season }(2016 / 2017)}{\text { Potassium humate (g/plant) }}$}} \\
\hline & & & & & & & & & \\
\hline & & 0 & 1 & 2 & $\begin{array}{l}\text { Mean } \\
(\mathbf{S} * \mathbf{N})\end{array}$ & 0 & 1 & 2 & $\begin{array}{l}\text { Mean } \\
\left(S^{*} \mathbf{N}\right)\end{array}$ \\
\hline \multirow{3}{*}{ Clay } & $\mathbf{0}$ & 0.22 & 0.25 & 0.27 & 0.25 & 0.23 & 0.27 & 0.29 & 0.26 \\
\hline & 3 & 0.27 & 0.29 & 0.32 & 0.29 & 0.31 & 0.34 & 0.35 & 0.33 \\
\hline & 6 & 0.33 & 0.36 & 0.39 & 0.36 & 0.37 & 0.38 & 0.41 & 0.39 \\
\hline \multirow{3}{*}{ Sand loamy } & $\mathbf{0}$ & 0.20 & 0.23 & 0.26 & 0.23 & 0.21 & 0.24 & 0.27 & 0.24 \\
\hline & 3 & 0.27 & 0.29 & 0.30 & 0.29 & 0.28 & 0.31 & 0.32 & 0.30 \\
\hline & 6 & 0.31 & 0.35 & 0.37 & 0.34 & 0.34 & 0.37 & 0.39 & 0.37 \\
\hline \multicolumn{2}{|c|}{ Mean (KH) } & 0.27 & 0.30 & 0.32 & \multirow{4}{*}{ Mean (S) } & 0.29 & 0.32 & 0.34 & \multirow{4}{*}{ Mean (S) } \\
\hline \multirow{3}{*}{ L.S.D 0.05} & KH & \multicolumn{3}{|c|}{0.002} & & \multicolumn{3}{|c|}{0.002} & \\
\hline & $\mathbf{S} * \mathbf{N}$ & \multicolumn{3}{|c|}{0.003} & & \multicolumn{3}{|c|}{0.002} & \\
\hline & $\mathbf{S} * \mathbf{N} * \mathbf{K H}$ & \multicolumn{3}{|c|}{0.005} & & \multicolumn{3}{|c|}{0.004} & \\
\hline \multirow{2}{*}{$\begin{array}{c}\text { Mean } \\
(\mathbf{S} * \mathbf{K H})\end{array}$} & Clay & 0.27 & 0.30 & 0.33 & 0.30 & 0.30 & 0.33 & 0.35 & 0.33 \\
\hline & Sand loamy & 0.26 & 0.29 & 0.31 & 0.29 & 0.28 & 0.31 & 0.33 & 0.30 \\
\hline \multirow[t]{2}{*}{ L.S.D 0.05} & $\mathbf{S}$ & \multicolumn{3}{|c|}{0.005} & Mean $(\mathbf{N})$ & \multicolumn{3}{|c|}{0.004} & Mean $(\mathrm{N})$ \\
\hline & $\mathbf{S * K H}$ & \multicolumn{3}{|c|}{0.003} & & \multicolumn{3}{|c|}{0.003} & \\
\hline \multirow{3}{*}{$\begin{array}{c}\text { Mean } \\
\left(\mathbf{N}^{*} \mathbf{K H}\right)\end{array}$} & $\mathbf{0}$ & 0.21 & 0.24 & 0.27 & 0.24 & 0.22 & 0.26 & 0.28 & 0.25 \\
\hline & 3 & 0.27 & 0.29 & 0.31 & 0.29 & 0.30 & 0.33 & 0.34 & 0.32 \\
\hline & 6 & 0.32 & 0.36 & 0.38 & 0.35 & 0.36 & 0.38 & 0.40 & 0.38 \\
\hline \multirow{2}{*}{ L.S.D 0.05} & $\mathbf{N}$ & \multicolumn{4}{|c|}{0.005} & \multicolumn{4}{|c|}{0.003} \\
\hline & $\mathbf{N * K H}$ & \multicolumn{4}{|c|}{0.004} & \multicolumn{4}{|c|}{0.003} \\
\hline
\end{tabular}

In a conclusion, the interaction between at a level of ammonium nitrate (6g/plant) and potassium humate ( $2 \mathrm{~g} /$ plant) increased $\mathrm{N}, \mathrm{P}$ and $\mathrm{K}$ contents compared with the control. In addition pigments such as Beta carotene and Xanthophyll in dry ray flowers were significantly increased with this interaction treatment as compared to untreated plants.

Fayoum J. Agric. Res. \& Dev., Vol. 33, No.2, July, 2019 
THE INFLUENCE OF AMMONIUM NITRATE AND POTASSIUM.... 144 LITERATURE CITED

Abbasi, D.; Rouzbehan, Y. and Rezaei, J. (2012): Effect of harvest date and nitrogen fertilization rate on the nutritive value of amaranth forage (Amaranthus hypochondriacus) plants. J. Animal Feed Sci. and Tech., (171): 6-13.

Abd El-Latif, W. M. A. (2018): Physiological studies on Calotropis (Calotropis procera) plant. M.Sc. Thesis. Fay. Univ. Fac. Of Agric.

Ali, A. H.; Shafeek, M. R.; Mahmoud, A. R. and El-Desuki, M. (2014): Effect of various levels of organic fertilizer and humic acid on the growth and roots quality of turnip plants (Brassica rapa). Current Sci. Inter., 3(1): 7-14.

Askar, F.A. (1988): Suitability of soil conditioners for desert and cultivated soilin Egypt. Inter. Synp. Soil conditioners, Egypt:133-142.

Bacot, A. M. (1954): Chemical composition of representative grands of the 1952 and 1954 crops of the crude tobacco. U. S. government printing office Washington.

Balack, R. S.; Tewari, S. K.; Singh, C. P. and Ram, B. (1999): Effect of nitrogen and plant spacings on the growth and flower yield of tuberose (Polianthes tuberosa L.) cv. Single on sodic soils. J. of Medicinal and Aromatic plant Sci., 21: (4), 959-962.

Chen, Y. and Aviad, T. (1990): Effects of humic substances on plant growth. Humic substances in soil and crop sciences: Selected readings (humic substances). pp. 161-186.

Cimrin, M. K. and Yilmaz, I. (2005): Humic acid applications to lettuce do not improve yield but do improve phosphorus availability, Acta Agriculturae Scandinavica, section B - Soil\& Plant Science, 55(1): 58-63.

Dole, J. M. and Wilkins, H. F. (2005): Floriculture, Principles and Species. 2nd ed. Upper Saddle River, New Jersey, USA: Pearson Education Inc. p. $1-995$.

El-Ghozoli, M. A. (2003): Influence of humic acid on faba bean plants grown in cadmium polluted soil. Annals of Agric. Sci., Moshtohor, Vol. 41 (4): $1787-1800$.

Gomaa, A. O. and Youssef, A. S. M. (2008): Efficiency of bio and chemical fertilization in presence of humic acid on growth performance of caraway. Safe Agriculture Products for Health and Environment by Using Recent Technologies Conference. May, National Research Centre Agricultural and Biological Research Division Cairo, Egypt. $1-31$.

Hafez, A. R. and Mikkelsen, D. S. (1981): Colorimetric determination of nitrogen for evaluating the nutritional status of rice. Commun. Soil Sci. and Plant Analysis, 12 (1): 61- 69.

Fayoum J. Agric. Res. \& Dev., Vol. 33, No.2, July, 2019 
Badran, A. Wesam, et, al.,

Ibrahim, O. A. (2013): Effect of chemical and bio-fertilizers on growth and chemical constituents of datura (Datura Innoxia Mill.) plants. M.Sc. Thesis, Fac. Agric. Fayoum Univ.

Jackson, M. L. (1967): Soil Chemical Analysis. New Delhi, Prentice Hall of India Private Limited, New Delhi, pp. 144-197 and 326-338.

Klute, A. (1986): Methods of Soil Analysis, Part 1, Physical and Mineralogical Methods ( $2^{\text {nd }}$ ed.). American Society of Agronomy, Madison, Wisconsin, U.S.A.

Marinari, S.; Masciandaro, G.; Ceccanti, B. and Grero, S. (2000): Influence of organic and mineral fertilizers on soil biology and physical properties. Bio Resource Techno., 72: 9 - 17.

Matter, F. M. A. (2015): Influence of compost on Calendula officinalis L. plants as affected by different agricultural drainage levels of irrigation water. Egypt, J. Hort. Vol. 42(2): 800 - 811.

Matter, F. M. A.; Agamy, R. A. and El-Ganain, S. S. (2009): Influence of nitrogen sources on yield and anatomical characters of damsisa (Ambrosia maritime, L) plants under sandy soil conditions. J. Agric. Sci. Mansoura Univ., 34(3): 1853 - 1867.

Mazhar, A. M.; Shedeed, S. I.; Abdel-Aziz, N.G. and Mahgoub, M. H. (2012): Growth, flowering and chemical constituents of Chrysanthemum indicum L. plant in response to different levels of humic acid and salinity. J. of Appl. Sci. Res., 8, 3697-3706.

Mohammadipour, Ehsan; Golchin, A.; Mohammadi, J.; Negahdar, N. and Zarchin, M. (2012): Effect of humic acid on yield and quality of Marigold (Calendula officinalis L.). Annals of Biolo. Res., 3(11):5095-5098.

Page, A.L.; Miller, R.H. and Kenney, D.R. (1982): Methods of Soil Analysis. Chemical and Microbiological Properties, Part 2, pp.; 3941. SSSP, Inc., Madison, Wisconsin, USA.

Piccolo, A.; Nardi, S. and Concheri, G. (1991): Structural characteristics of humic substances as related to nitrate uptake and growth regulation in plant systems. Soil Bio. Biochem., 23: 833 - 836.

Pizzeghello, D.; Nicolini, G. and Nardi, S. (2001): Hormone-like activity of humic substances in Fagus sylvaticae forests. New Phytologist, 51: $647-657$.

Prakash, P.; Rajakumari, P.; Aishwarya, V.; Thanuja, P.; Archana, P. V. and Thirumurugan, A. (2012): The influence of potassium humate on Stevia rebaudiana. Intern. J. Agri \& food Sci., 2(1): 30-3.

Russo, R. O. and Berlyn, G. P. (1990): The use of organic bio-stimulants to help low input sustainable agriculture. J. Sustainable Agric. 1: 19 42.

Shafeek, M. R.; Helmy, Y. I. and Ahmed, A. A. (2016): Productivity of squash plant to mineral and bio-nitrogen fertilizers on plant growth,

Fayoum J. Agric. Res. \& Dev., Vol. 33, No.2, July, 2019 
THE INFLUENCE OF AMMONIUM NITRATE AND POTASSIUM.... 146 total fruit yield and leaves mineral content on a sandy soil. Inter. J. Chem Tech Res., 9(03): 66-75.

Shahin, S. M.; El-Sayed, B. A. and El-Tayeb, H. F. (2014): Improving growth and quality of Merremia dissecta (Jaca.) H. G. hallier twiner by some fertilization treatments. Alex. J. Agri. Rese., 59(1): 43-49.

Sharif, M.; Khattak, R. A. and Sarir, M. S. (2002): Effect of different levels of lignitic coal derived humic acid on growth of maize plants. Communication in Soil Science and Plant Analysis 33:3567-3580.

Sifola, Maria, I. and Barbieri, G. (2006): Growth, yield and essential oil content of three cultivars of basil (Ocimum basilicum L.) grown under different levels of nitrogen in the field. Sci. Horti., (108): 408413.

Singh, A.; Godara, N. R. and Ashok-Kumar, N. R. (1996): Effect of NPK on bulbs production in tuberose (Polianthes tuberosa L.) cv. Single. Haryana. Agric. Univ. J. Res., 26: (3), 187-190.

Steel, R. G. D and Torrie, J. H. (1980): Principles and Procedures of Statistics. A biometrical approach. 2nd Ed., McGraw Hill Inter. Book Co. Tokyo, Japan.

Yassen, A. A.; Mazhar, A. A. M. and M. S . Z. (2010): Response of anise plants to nitrogen fertilizer and foliar spray of tryptophan under agricultural drainage water. New York Sci. J. 3; (9): 120 - 127.

Zhang, X. Z. and Ervin, E. H. (2004): Cytokinin-containing seaweed and humic acid extracts associated with creeping bentgrass leaf cytokinins and drought resistance. Crop Sci., 5: 1737-1745.

Fayoum J. Agric. Res. \& Dev., Vol. 33, No.2, July, 2019 
تأثير نترات الأمونيوم وهيومات البوتاسيوم علي التركيب الكيماوي لنبات الأقحوان تحت ظروف

Badran, A. Wesam, Selim, S.M., Abdella, M. Ebtsam, Matter, F.M.A

قسم البساتين، كلية الزراعة، جامعة الفيوم (مصر)

E-mail:Wa1289@fayoum.edu.eg

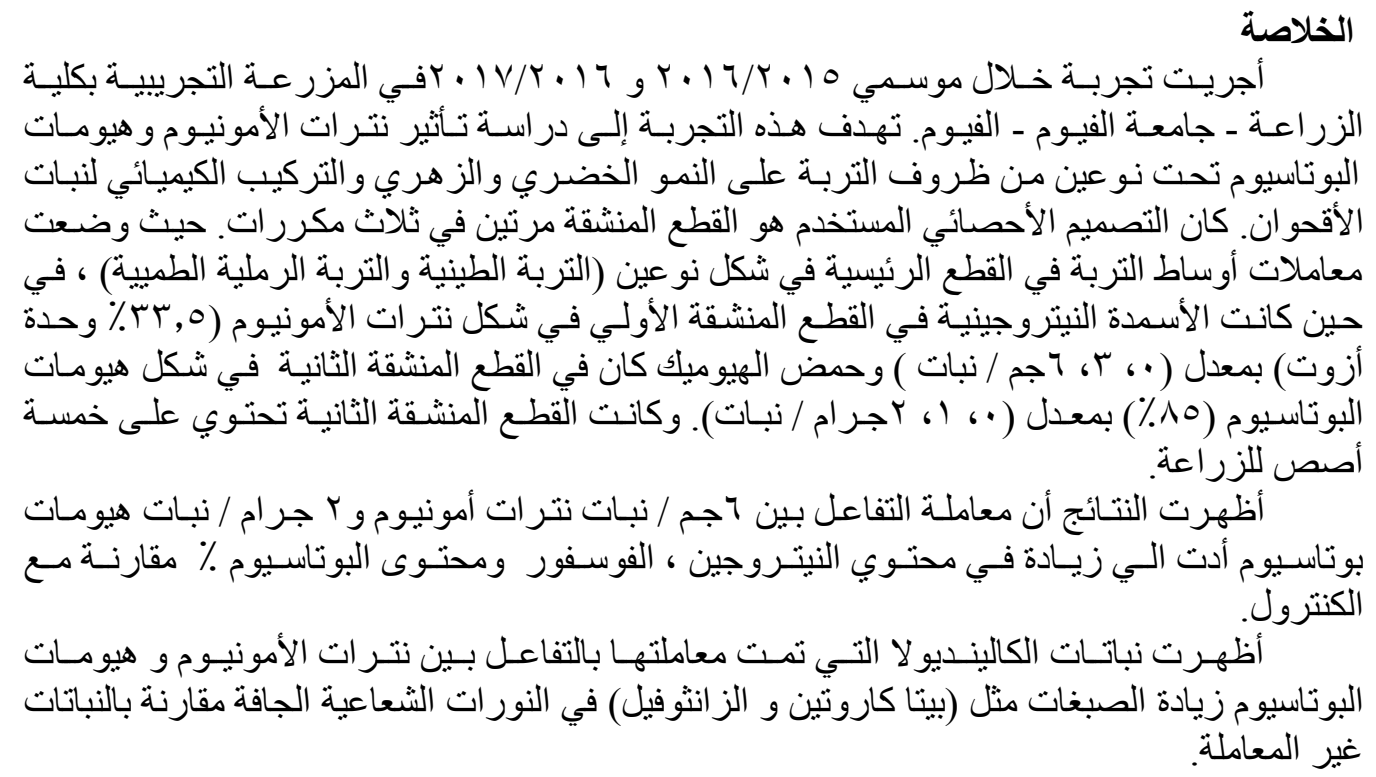

Fayoum J. Agric. Res. \& Dev., Vol. 33, No.2, July, 2019 